\title{
Population structure and reproductive period of two introduced fish species in a Brazilian semiarid region reservoir
}

\author{
Marla Melise de Oliveira Sousa, Suzany Iasnaya Moreira Lopes, Rodrigo Silva da Costa \\ \& José Luís Costa Novaes* \\ Departamento de Ciências Animais, Universidade Federal Rural do Semi-Árido, Costa e Silva, Mosoró (RN), 59625- \\ 900,Brazil; marla_melise@hotmail.com, suzanymoreira@hotmail.com,rdgcosta@ufersa.edu.br, \\ novaes@ufersa.edu.br \\ * Correspondence
}

Received 01-IX-2014. C Corrected 22-II-2015. Accepted 20-III-2015.

\begin{abstract}
The Amazonian fish species Plagioscion squamosissimus (Sciaenidae) and Cichla monoculus (Cichlidae), have been widely introduced into different reservoirs in Brazil, and have caused many negative impacts on local fish fauna. The aim of this study was to evaluate the population structure (abundance, length structure, length-weight relationship, sex ratio, and length at first maturity) and the reprodutive period of these two species in the Santa Cruz Reservoir (built in 2002), located in the Brazilian semiarid region, for their adequate management and local species conservation policies. Specimens were collected quarterly in eight sites from February 2010 to November 2013 using gillnets (12 to $70 \mathrm{~mm}$ mesh between adjacent knots). The specimens captured were counted and the following biometric and biological data were analysed: standard length, total weight, and reproductive data, such as, sex, weight and gonadal maturity stage. The species abundances were estimated by CPUE and expressed as the number of individuals per gill net area $\mathrm{x}$ gill net exposition time $\left(\mathrm{m}^{2} \mathrm{x} \mathrm{h}\right)$; length frequency histograms were built with intervals of $5 \mathrm{~cm}$. The length-weight parameters were estimated with a linear regression after a logarithmic transformation of the data. With the reproductive data we estimated sex ratio, reproduction period and length at first maturity $\left(\mathrm{L}_{50}\right)$. We captured a total of 1071 specimens of P. squamosissimus and 156 specimens of C. monoculus. Both species showed higher abundances in 2010, $0.004306 \mathrm{~m}^{2} \mathrm{x} \mathrm{h}$ and $0.00022 \mathrm{~m}^{2} \mathrm{x}$ h, respectively, but this parameter decreased from 2010 to 2013. Standard length ranged between 6.4 and $46.2 \mathrm{~cm}$ for P. squamosissimus (20.025.0 cm was the most frequent class), and 7.0 and $38.7 \mathrm{~cm}$ for $C$. monoculus (10.0-15.0 cm was the most frequent class). The length-weight relationships were described by the following equations: $\log _{10} \mathrm{Wt}=-1.8349+3.0899 \log _{10} \mathrm{Lp}$ and $\mathrm{R}^{2}=0.9795$ for $P$. squamosissimus, and $\log _{10} \mathrm{Wt}=-1.7944+3.0885 \log _{10} \mathrm{Lp}$ and $\mathrm{Wt}=0.0160$ and $\mathrm{R}^{2}=0.9929$ for $C$. monoculus; both species exhibited positive allometric growth. The sex ratio for both species differed from 1:1, with a predominance of females for $P$. squamosissimus and males for $C$. monoculus. The $\mathrm{Lp}_{50}$ was estimated to be $15.90 \mathrm{~cm}$ for $P$. squamosissimus and $15.65 \mathrm{~cm}$ for $C$. monoculus, and the reproductive data indicated that both species reproduced throughout the year. We concluded that although the population of both species reduced their abundance over the study period, P. squamosissimus and C. monoculus are established and structured populations in the Santa Cruz Reservoir with individuals growing satisfactorily and reproducing in all seasons, without a well-defined reproductive peak. We suggest that the managers may allow the artisanal and/or sport fisheries of these species. Rev. Biol. Trop. 63 (3): 727-739. Epub 2015 September 01.
\end{abstract}

Key words: Cichla monoculus, Plagioscion squamosissimus, dam, population structure, reproductive period.

In Brazil the most common direct causes of biodiversity loss in inland waters are impoundments and species introductions (Agostinho, Gomes, Verissímo, \& Okada, 2004). River impoundments have occurred for many reasons, being the flood control and the water supply, the most important in the Brazilian semiarid region (Paiva, Petrere Jr., Petenate, Nepomuceno, \& Vasconcelos, 1994; Chellapa, Bueno, Chellappa, Chellappa, \& Val, 2009). However, 
the transformation of the fluvial environment into a lentic or semi-lentic environment, has caused numerous modifications, such as changes in the fish assemblages and declines in fishery resources (Petry, Agostinho, \& Gomes, 2003). In Brazil, in order to mitigate the reservoir construction negative effects on fish fauna and fishery resources, the main measure adopted was stocking the reservoirs with the exotic Amazonian species of Plagioscion squamosissimus, Sciaenidae (Heckel, 1840) and Cichla monoculus, Cichlidae Agassiz, 1831 (Agostinho, Gomes, \& Pelecice, 2007). However, these species have become a threat to the aquatic ecosystem and to the native fish fauna, by decreasing the abundance of native species via competition or predation; and in some places, this has led to local extinctions as in the Upper Paraná River basin (Gozlan, Britton, Coex, \& Copp, 2010; Barros, Santos, Zanncio \& Dergam, 2012; Britton \& Orsi, 2012).

Plagioscion squamosissimus and C. monoculus have established population with high abundance and successfully colonized different Brazilian reservoirs such as: Itaipu, Capivara and Três Maria (Agostinho et al., 2007). Plagioscion squamosissimus can reach $80.0 \mathrm{~cm}$ of total length and weight $4.5 \mathrm{~kg}$ (Froese \& Pauly, 2014), has a high fecundity and a long reproductive period with a peak during the rainy season (Godinho, Lamas, \& Godinho, 2010); previous studies have shown that the first maturity $\left(\mathrm{L}_{50}\right)$ can vary between $17.80 \mathrm{~cm}$ and $32.40 \mathrm{~cm}$ (Carnelós \& Benedito-Cecilio, 2002; Rocha, Juras, Cintra, \& Souza, 2006). The species occupies diverse biotopes and carries out its biological cycle in freshwater as well as in brackish water. Juveniles feed on larvae of crustaceans, aquatic insects and copepods; but adults prey on fish (Casatti, 2003). Cichla monoculus can reach $80.0 \mathrm{~cm}$ of total length and weight $9.0 \mathrm{~kg}$ (Froese \& Pauly, 2014) also has a long reproductive period, but in contrast with P. squamosissimus, there is no evidence of a reproductive peak throughout the year (Godinho et al., 2010); the first maturity $\left(\mathrm{L}_{50}\right)$ is about $21.0 \mathrm{~cm}$ length (Gomiero \& Braga, 2004). Juveniles feed on shrimps and microcrustaceans, while adults are almost exclusively piscivores (Novaes, Caramaschi, \& Winemiller, 2004).

The Santa Cruz Reservoir from the Brazilian semiarid region, is a relatively new dam (created in 2002), with scarce information on its fish populations structure and reproduction, especially for these two introduced fish species, that require adequate management for the preservation of native species. The aim of this study was to analyse the population biology (abundance, length structure, sex ratio, length at first gonadal maturation, length-weight relationship, and reproductive period) of the exotic amazon species $P$. squamosissimus and C. monoculus in this reservoir.

\section{MATERIALS AND METHODS}

Study area: The Brazilian semiarid region, localized in the Northeastern area of the country, has two well-defined seasons: dry (June-January) and rainy (February-May); it is characterized by irregular and scarce rains (200-800 mm/year), low thermal amplitude $\left(25-30{ }^{\circ} \mathrm{C}\right)$, and a high rate of evaporation. As a consequence, the hydrographic network of the semiarid is intermittent and moderate compared to that of other Brazilian regions, and reservoirs of different sizes have been constructed to supply cities in the region with water (Chellapa et al., 2009).

Among the small watersheds located inside the Northeast Atlantic basin is the Apodi/Mossoró River, which has an area of $14246 \mathrm{~km}^{2}$ and is the main river of the basin. It contains 22 reservoirs that supply water for human consumption and agriculture. The average annual rainfall in this watershed is $750 \mathrm{~mm}$, and it is concentrated between the months of February and June (Almeida, Cullar, Costa, \& Amorim, 2005). The Santa Cruz dam (5 $45^{\prime} 45^{\prime \prime} \mathrm{S}$ $\left.37^{\circ} 48^{\prime} 00^{\prime \prime} \mathrm{W}\right)$ is the largest $\left(38.95 \mathrm{~km}^{2}\right)$ of the water supply reservoirs $\left(6\right.$ million $\left.\mathrm{m}^{3}\right)$ in this watershed, and it is located in the municipality of Apodi.

Data collection: Fish samples were collected quarterly from February 2010 to 
November 2013 at eight fixed sites in the reservoir (Table 1). Sampling involved the use of gillnets with 12 to $70 \mathrm{~mm}$ mesh between adjacent knots; the nets were $15 \mathrm{~m}$ long and 1.8-2 m high, were set at 17:00 and retrieved at 05:00.

TABLE 1

Geographic location of the Santa Cruz Reservoir and of the sampling sites

\begin{tabular}{cl} 
Santa Cruz Reservoir & $05^{\circ} 45^{\prime} 45^{\prime \prime} \mathrm{S}-37^{\circ} 48^{\prime} 00^{\prime \prime} \mathrm{W}$ \\
Site 1 & $05^{\circ} 45^{\prime} 07^{\prime} \mathrm{S}-37^{\circ} 48^{\prime} 45^{\prime \prime} \mathrm{W}$ \\
Site 2 & $05^{\circ} 45^{\prime} 32^{\prime} \mathrm{S}-37^{\circ} 49^{\prime} 51^{\prime \prime} \mathrm{W}$ \\
Site 3 & $05^{\circ} 47^{\prime} 47^{\prime \prime} \mathrm{S}-37^{\circ} 49^{\prime} 34^{\prime \prime} \mathrm{W}$ \\
Site 4 & $05^{\circ} 48^{\prime} 28^{\prime \prime} \mathrm{S}-37^{\circ} 48^{\prime} 32^{\prime} \mathrm{W}$ \\
Site 5 & $05^{\circ} 47^{\prime} 54^{\prime \prime} \mathrm{S}-37^{\circ} 51^{\prime} 06^{\prime \prime} \mathrm{W}$ \\
Site 6 & $05^{\circ} 50^{\prime} 32^{\prime \prime} \mathrm{S}-37^{\circ} 52^{\prime} 22^{\prime} \mathrm{W}$ \\
Site 7 & $05^{\circ} 49^{\prime} 12^{\prime \prime} \mathrm{S}-37^{\circ} 52^{\prime} 51^{\prime \prime} \mathrm{W}$ \\
Site 8 & $05^{\circ} 50^{\prime} 29^{\prime \prime} \mathrm{S}-37^{\circ} 54^{\prime} 06^{\prime \prime} \mathrm{W}$ \\
\hline
\end{tabular}

The samples were transported immediately to the biology laboratory, where they were identified using technical guides (Rosa, Menezes, Bristski, Costa, \& Groth, 2003; Kullander \& Ferreira, 2006), the specimens were counted and routine biometric data were collected: standard length $(\mathrm{cm})$, total weight $(\mathrm{g})$, sex (determined by macroscopic observation of gonads as female, male, or immature), gonad weight (g), and maturation stage (immature, maturing, ripe, spent, and at rest) (Brown-Peterson, Wyanski, Saborido-Rey, Macewisc, \& Lowerre-Barbieri, 2011) The identification of specimens was confirmed by taxonomists from the Federal University of Paraíba (Universidade Federal da Paraíba-UFPB), and samples were deposited in the ichthyological collection of the institution (catalogue numbers UFPB 8933 8997). The monthly rainfall (categories according to recorded rainfall were very dry, dry, average, rainy, and very rainy) and water level benchmark for the reservoir were obtained from the websites of the Agricultural Research Corporation of Rio Grande do Norte (Empresa de Pesquisa Agropecuária do Rio Grande do Norte - EMPARN; http://www.emparn. rn.gov.br/contentproducao/aplicacao/emparn/ pesquisa/gerados/meteorologia.asp) and the State Secretary of the Environment and Water
Resources (Secretaria Estadual de Meio Ambiente e Recursos Hídricos - SEMARH; http:// www.semarh.rn.gov.br/contentproducao/aplicacao/semarh/sistemadeinformacoes/consulta/ cBaciaSitVolumetrica_Detalhe.asp?Codigo Estadual $=00$ ), respectively.

The abundance values of the two species were estimated by capture per unit effort (CPUE) and expressed as number of individuals: CPUE $=\mathrm{N} /\left(\mathrm{m}^{2} \mathrm{xh}\right)$, where $\mathrm{N}=$ number of individuals captured; $\mathrm{m}^{2}=$ gill net area (301. $8 \mathrm{~m}^{2}$ per site); and $\mathrm{h}=$ gill net exposition time (12 hours). The length structure of each population was evaluated using the length frequency histogram method constructed with intervals of $5 \mathrm{~cm}$. To examine the length-weight relationship of each population, we used the following mathematical expression after a logarithmic transformation of the data: $\log _{10} \mathrm{Wt}=\mathrm{a}+\mathrm{b}$ $\log _{10} \mathrm{Lp}$ (Froese, 2006), where $\mathrm{Wt}=$ total weight, $\mathrm{Lp}=$ standard length, $\mathrm{a}=$ constant, and $b=$ inclination of slope. The sex ratio was obtained using the gender data. According to maturity stage, fish were considered to be "juvenile" (immature stage) or "adult" (other stages), and the length of first maturation $\left(\mathrm{L}_{50}\right.$ $=$ length at which $50 \%$ of the individuals attain gonadal maturity for the first time) was analysed using the generalized linear model (GLM) by fitting a logistic regression equation, with standard length as the independent variable:

$$
P_{\text {maturity }}=\exp ^{(\mathrm{a}+\mathrm{b}+L) *}\left[1+\exp ^{(\mathrm{a}+\mathrm{b}+L)}\right]^{-1}
$$

where $\mathrm{P}_{\text {maturity }}=$ the estimated proportion of mature individuals in relation on total length $(L)$. Coefficients were estimated using iteratively reweighted least square analysis. Only females were used for the reproductive period analysis because they are better indicators of the reproductive period (Wootton, 1995). In our temporal analysis the data were grouped by season [rainy (February and May) and dry (August and November)], and the reproductive period was evaluated using the following techniques: distribution and frequency of macroscopic stages of ovarian development, where fish were considered to be reproductive 
(maturation, ripe, and spent) and non-reproductive (rest), and the seasonal average of the gonadosomatic index (GSI):

$$
\mathrm{GSI}=(\mathrm{Wg} / \mathrm{Wt}) * 100
$$

where $\mathrm{Wg}=$ gonad weight and $\mathrm{Wt}=$ total weight of fish.

All statistical analyses were carried out in $\mathrm{R}$ ver. 3.0.2 ( $\mathrm{R}$ Development Core Team, 2013), and $p<0.05$ was considered to be statistically significant. Continuous data (CPUE and GSI) were $\log _{10}$ transformed and tested for normality and homogeneity of variances using a Shapiro-Wilk test and the Bartlett test, respectively (Zar, 1996). Once the tests confirmed normality and variance homogeneity, data were compared using analysis of variance (ANOVA), and Tukey's test was used to detect statistical differences. The correlation coefficient ( $r$ ) was used to correlate accumulated rainfall $(\mathrm{mm})$ and the water level benchmark of the reservoir with the $\log _{10}$-transformed values of CPUE and GSI. The t-test was used to determine whether the value of $b$ of the length-weight relationship was equal to 3 (the condition of isometric growth) (Froese, 2006). The chi-square $\left(\chi^{2}\right)$ test was used to determine if the male to female ratio of each population was 1:1 and if there were differences between reproductive and non-reproductive individuals for each season.

\section{RESULTS}

The total accumulated precipitation in the Santa Cruz Reservoir region during each year of the study was $633.8 \mathrm{~mm}$ (average) in 2010, $901.7 \mathrm{~mm}$ (rainy) in 2011, $202.5 \mathrm{~mm}$ (very dry) in 2012, and $493.7 \mathrm{~mm}$ (dry) in 2013. The highest precipitation was observed in the first months of the year (January-May), and the maximum value was observed in April 2013 (287.5 mm). The water level benchmark of the Santa Cruz Reservoir decreased throughout the study from $86.31 \mathrm{~m}(93.38 \%$ of reservoir's capacity) in January 2010, to $41.0 \mathrm{~m}(49.03 \%)$ in December 2013 (Fig. 1).

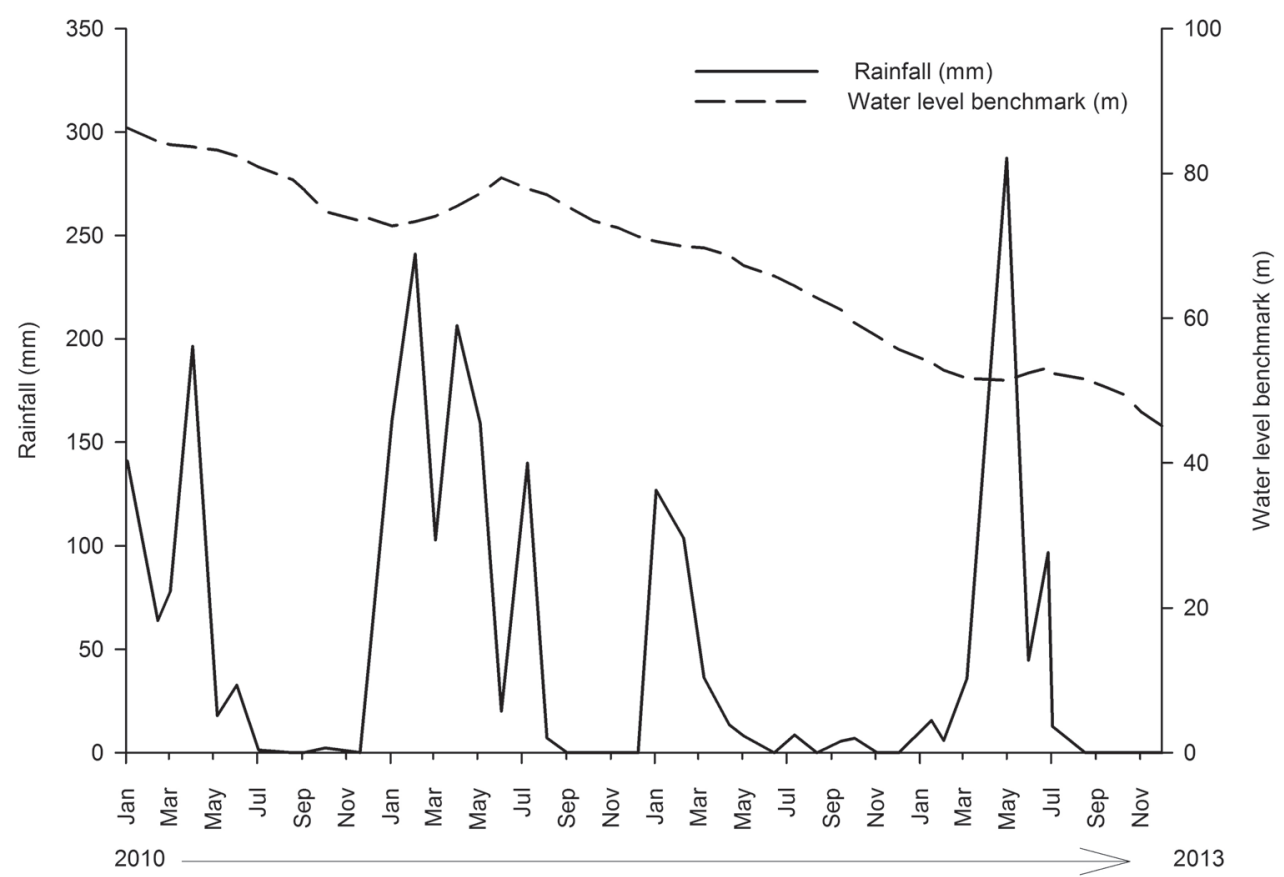

Fig. 1. Rainfall data ( $\mathrm{mm}$ ) for the municipality of Apodi and the water level benchmark (m) for the Santa Cruz Reservoir in the Apodi/Mossoro River during the study period. 
We captured 1071 specimens of $P$. squamosissimus and 156 specimens of $C$. monoculus. The highest CPUE values for both species occurred in 2010 [0.004306 $(\mathrm{SD}=0.0021)$ ind. $\mathrm{m}^{2} / \mathrm{h}$ for $P$. squamosissimus and 0.0004401 (SD $=0.00022$ ) ind. $\mathrm{m}^{2} / \mathrm{h}$ for $C$. monoculus $]$. The CPUE for both species declined in subsequent years of the study; significant differences among years was indicated for P. squamosissimus (ANOVA, $\mathrm{F}_{1: 3}=4.121 ; \mathrm{P}=0.0318$ ) but not for C. monoculus (ANOVA, $\mathrm{F}_{1: 3}=0.787$; $\mathrm{P}$ $=0.524$ ) (Fig. 2). No correlations between the CPUE values of the two species and the environmental variables (accumulated rainfall and water level) were detected (Pearson, $\mathrm{P}>0.05$ ).

Standard length and total weight of species ranged between $6.4 \mathrm{~cm}$ and $46.2 \mathrm{~cm}$ and 5.5 $\mathrm{cm}$ and $2233.50 \mathrm{~g}$, respectively, for $P$. squamosissimus and $7.0 \mathrm{~cm}$ and $38.7 \mathrm{~cm}$ and $6.0 \mathrm{~g}$ and $1201.30 \mathrm{~g}$ for $C$. monoculus. The length structure for the whole period showed that the most frequent length class was 20.0-25.0 $\mathrm{cm}$ for $P$. squamosissimus and 10.0-15.0 cm for C. monoculus (Fig. 3). The length-weight relationship can be described by $\log _{10} \mathrm{Wt}=$ $-1.8349+3.0899 \log _{10} \mathrm{Lp}$ and $\mathrm{R}^{2}=0.9795$ for $P$. squamosissimus and $\log _{10} \mathrm{Wt}=-1.7944+3.0885$ $\log _{10} \mathrm{Lp}$ and $\mathrm{R}^{2}=0.9929$ for $C$. monoculus. The results showed that both species exhibited positive allometric growth (t-test, $\mathrm{P}<0.001$ ).

During the study period, 463 female (56.4 $\%)$ and 358 male (43.6 \%) P. squamosissimus and 46 female (39.31\%) and 71 male (60.68 $\%)$ C. monoculus were captured, indicating a sex ratio that differed significantly from $1: 1\left(\chi^{2}=13.17, \mathrm{P}<0.001\right.$ and $\chi^{2}=3.64$, $\mathrm{P}<0.05$, respectively)

We captured 452 immature $P$. squamosissimus individuals with standard length varying from $6.4 \mathrm{~cm}$ to $22.0 \mathrm{~cm}$ and $70 \mathrm{~cm}$ immature C. monoculus individuals with standard length varying from $7.0 \mathrm{~cm}$ to $18.0 \mathrm{~cm}$. The two species exhibited a similar first maturation pattern in relation to length. The parameter estimates of the model, with confidence intervals in parentheses, were: $a=-4.39$ and $b=0.94$ and

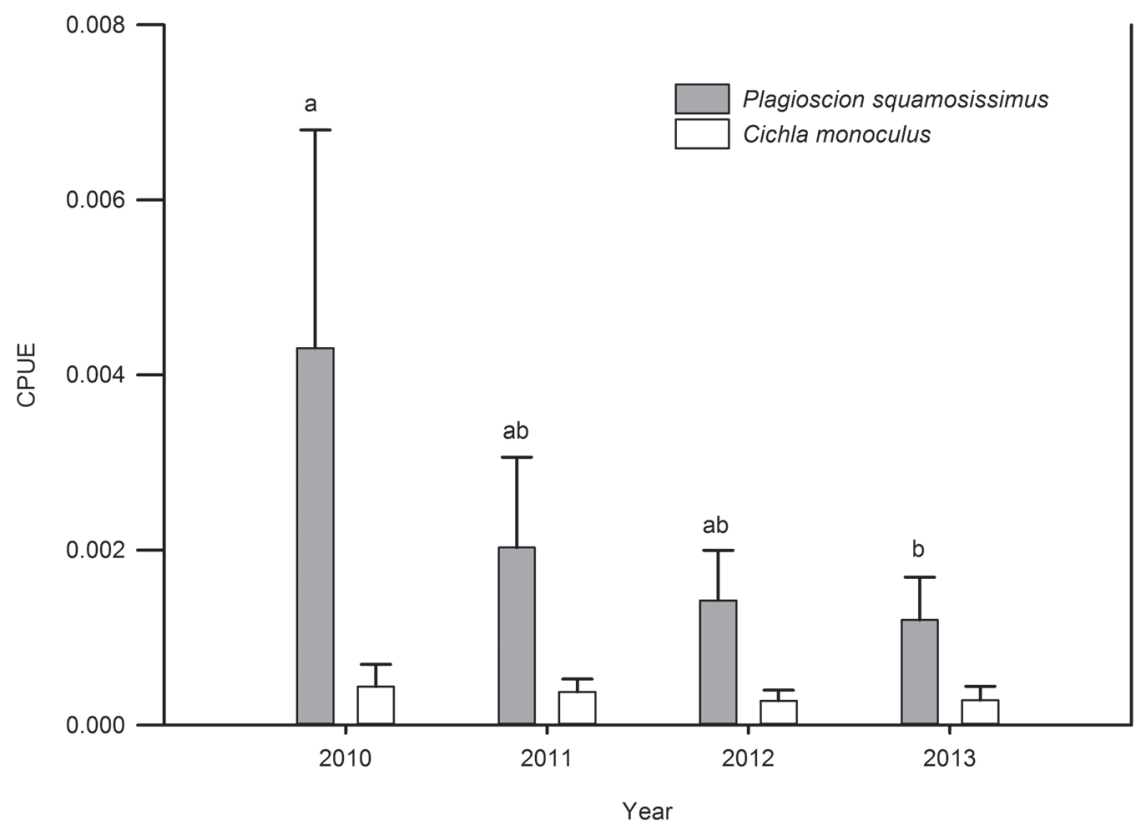

Fig. 2. Temporal variation of the capture per unit effort (CPUE) data for A) Plagioscion squamosissimus and B) Cichla monoculus in the Santa Cruz Reservoir, Apodi/Mossoró River. Bars represent mean values; lines indicate standard deviation values. Different letters for Plagioscion squamosissimus indicate statistical differences (ANOVA, P $<0.05$ ). For Cichla monoculus no significant differences was detected (ANOVA, $\mathrm{P}>0.05$ ). 

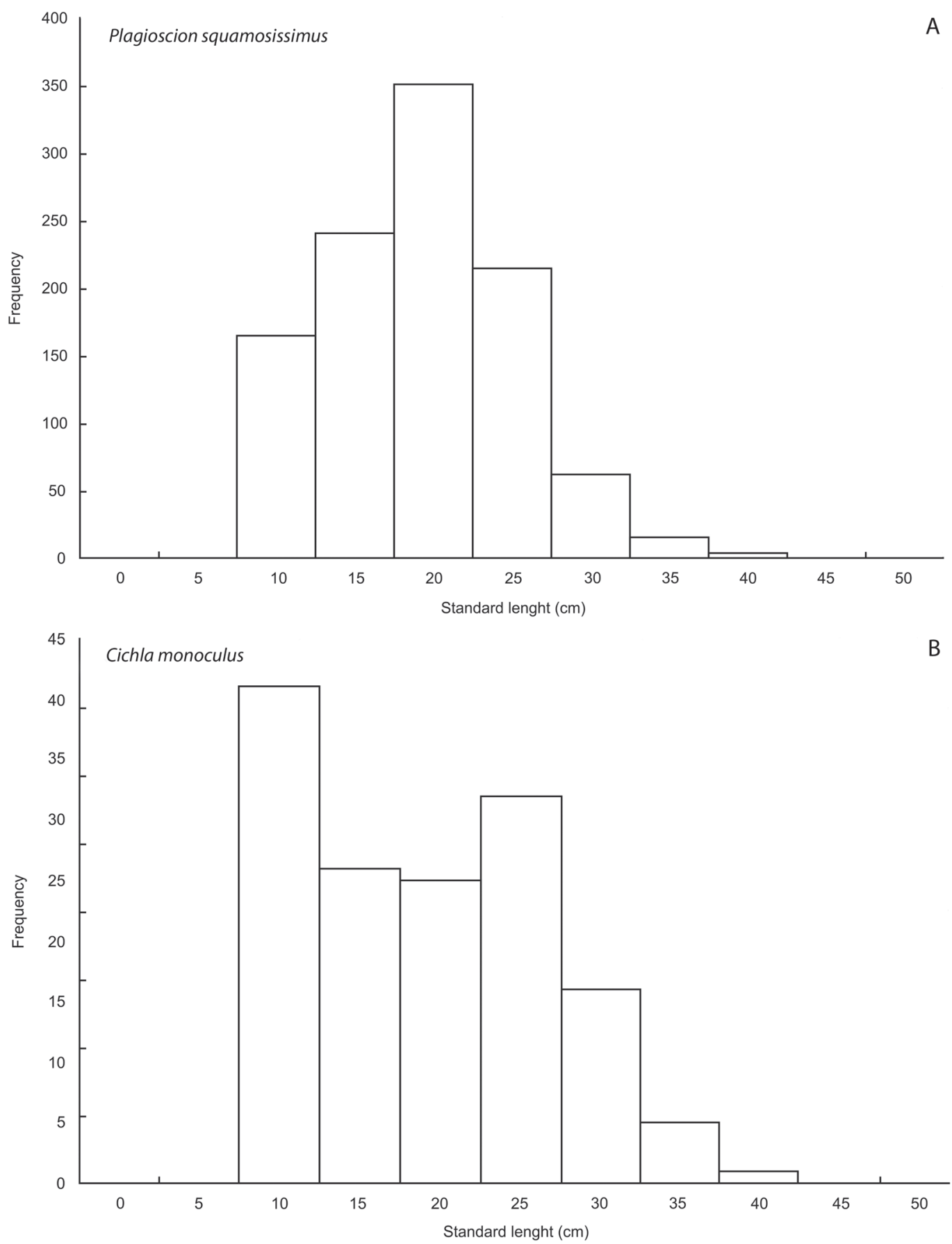

Fig. 3. Frequency histogram showing the length distribution (by standard length class (cm) of A) Plagioscion squamosissimus and B) Cichla monoculus in the Santa Cruz Reservoir, Apodi/Mossoró River. 
$\mathrm{Lp}_{50}=15.90 \mathrm{~cm}(\mathrm{CI}=15.68-6.13)$ for $P$. squamosissimus and $\mathrm{a}=-15.94$ and $\mathrm{b}=1.01$ and $\mathrm{Lp}_{50}=15.65 \mathrm{~cm}(\mathrm{CI}=15.01-16.70)$ for $C$. monoculus (Table 2).

Analysis of the females maturity stage showed that reproductive specimens were predominant $\left(\chi^{2}, \mathrm{P}<0.05\right)$ in all seasons for $P$. squamosissimus. For $C$. monoculus reproductive specimens were not captured during the rainy period in 2010 and during the dry period in $2011\left(\chi^{2}, \mathrm{P}<0.05\right.$ in dry/2011 and rainy/2013) (Table 3). The average GSI for $P$. squamosissimus varied between 1.19 (rainy 2013) and 2.05 (dry 2013), and no significant differences between seasons were detected (ANOVA, $\mathrm{F}_{1: 7}=1.359 ; \mathrm{P}=0.221$ ). For $C$. monoculus, the average GSI values ranged from 0.09 (rainy 2010) to 1.87 (dry 2013), with significant differences detected between seasons (ANOVA, $\mathrm{F}_{1: 7}=3.908 ; \mathrm{P}<0.01$ ). No correlations between the GSI values of the two species and the environmental variables (accumulated rainfall and water level) were detected (Pearson, $\mathrm{P}>0.05$ ).

\section{DISCUSSION}

The rainfall during the first two years of the study varied from normal to rainy, and during the last two years it was below average (very dry and dry). As a consequence, the water level benchmark for the reservoir decreased throughout the study. This irregular pattern of rainfall is characteristic of Northeastern Brazil (Ab'Sáber, 1995), and periods of drought, as occurred in 2012 and 2013, may periodically reduce the abundance of populations of aquatic organisms (Bond, Lake, \& Arthington, 2008). Although the abundances of $P$. squamosissimus and $C$. monoculus declined during the study period, there was no correlation with decreasing rainfall or the water level benchmark. Thus, the observed reduction in abundance may have been caused by transformations that occur in the aquatic environment until the new ecosystem reaches ecological stability. In the early years after reservoir instalation, biological production increased due to the release of a large amount of dissolved nutrients via the decomposition of flooded organic matter; during this

TABLE 2

Comparative data for length at first maturity of Plagioscion squamosissimus and Cichla monoculus for the present investigation and from previous research

\begin{tabular}{lccc}
\multicolumn{1}{c}{ Species } & First maturation (cm) & Site (Country) & Reference \\
Cichla monoculus & 15.65 & Santa Cruz (Brazil) & Present investigation \\
Cichla kelberi & 20.7 (females); 21.5 (males) & Lobo (Brazil) & Souza et al. (2008) \\
Cichla kelberi & 19.2 & Leme (Brazil) & Gomiero et al. (2009) \\
Cichla melaniae & 26.45 & Xingu River (Brazil) & Camargo \& Júnior (2007) \\
Cichla monoculus & 21.4 (females); 26.2 (males) & Campo Grande (Brazil) & Chellappa et al. (2003) \\
Cichla monoculus & 21.5 & Volta Grande (Brazil) & Gomiero \& Braga (2004) \\
Cichla ocellaris & 32.2 (females); 33.2 (males) & Gatun Lake (Panama) & Zaret (1980) \\
Cichla ocellaris & 20.0 & Volta Grande (Brazil) & Gomiero \& Braga (2004) \\
Cichla piquiti & 22.5 & Cachoeira Dourada (Brazil) & Luiz et al. (2011) \\
Plagioscion squamosissimus & 15.90 & Santa Cruz (Brazil) & Present investigation \\
Plagioscion magdalenae & 22.25 & Xingu River (Brazil) & Camargo \& Júnior (2007) \\
Plagioscion magdalenae & 27.9 & Bay Marajó(Brazil) & Santos et al. (2010) \\
Plagioscion squamosissimus & 21.60 & Barra Bonita (Brazil) & Castro (1999) \\
Plagioscion squamosissimus & 17.80 & Itaipú (Brazil) & Carnelós \& Benedito-Cecilio (2002) \\
Plagioscion squamosissimus & 24.50 & Pentecoste (Brazil) & Santos et al. (2003) \\
Plagioscion squamosissimus & 32.40 & Tucuruí (Brazil) & Rocha et al.(2006) \\
Plagioscion squamosissimus & 24.96 & Xingu River (Brazil) & Camargo \& Júnior (2007) \\
Plagioscion squamosissimus & 16.1 (females);21.4 (males) & Pará River (estuary) (Brazil) & Barbosa et al. (2012) \\
\hline
\end{tabular}


TABLE 3

Number of reproductive and non-reproductive individuals with the results of the chi-square test $\left(\chi^{2}\right)$ and average values of the gonadossomatic index (GSI) by season for Plagioscion squamosissimus and Cichla monoculus in the Santa Cruz Reservoir, Apodi/Mossoró River

\begin{tabular}{lcccccccc}
\multicolumn{4}{c}{ Plagioscions squamosissimus } & \multicolumn{5}{c}{ Cichla monoculus } \\
Season & Non-reproductive & Reproductive & $\chi^{2}$ & GSI & Non-reproductive & Reproductive & $\chi^{2}$ & GSI \\
Rainy/2010 & 16 & 140 & $96.98^{*}$ & $1.414^{\mathrm{a}}$ & 4 & 0 & 2.25 & $0.096^{\mathrm{a}}$ \\
Dry/2010 & 8 & 59 & $37.31^{*}$ & $1.647^{\mathrm{a}}$ & 1 & 6 & 2.28 & $1.522^{\mathrm{b}}$ \\
Rainy/2011 & 0 & 58 & $56.01^{*}$ & $1.803^{\mathrm{a}}$ & 0 & 5 & 3.20 & $0.700^{\mathrm{ab}}$ \\
Dry/2011 & 17 & 29 & $2.63^{*}$ & $1.804^{\mathrm{a}}$ & 7 & 0 & $5.17^{*}$ & $0.357^{\mathrm{a}}$ \\
Rainy/2012 & 1 & 69 & $64.12^{*}$ & $1.649^{\mathrm{a}}$ & 2 & 5 & 0.57 & $0.900^{\mathrm{ab}}$ \\
Dry/2012 & 1 & 17 & $12.5^{*}$ & $1.553^{\mathrm{a}}$ & 1 & 4 & 0.80 & $1.600^{\mathrm{b}}$ \\
Rainy/2013 & 8 & 23 & $6.32^{*}$ & $1.194^{\mathrm{a}}$ & 0 & 6 & $4.16^{*}$ & $1.512^{\mathrm{b}}$ \\
Dry/2013 & 5 & 12 & 2.11 & $2.057^{\mathrm{a}}$ & 0 & 5 & 3.20 & $1.773^{\mathrm{b}}$ \\
\hline
\end{tabular}

* indicate the statistical differences $(\mathrm{P}<0.05)$ between non-reproductive and reproductive individuals per season. Different letters indicate the statistical differences $(\mathrm{P}<0.05)$ average values of the GSI among season to each species. Tukey HSD test.

period, known as the trophic upsurge period, this nutrient input increased production at all trophic levels. After this period, a trophic depression period began; during this phase, a decrease of nutrients occurred and consequently primary and secondary productivities declined (Petrere Jr., 1996) until the reservoir reached ecological stability; duration of this process varies among reservoirs and may take from 10 to 30 years (Lowe-McConnell, 1987). The Santa Cruz Reservoir was formed in 2002, so it is likely in the trophic depression period; the observed decrease in the abundances of $P$. squamosissimus and C. monoculus may be related to this phenomenon.

Plagioscion squamosissimus was more abundant than C. monoculus, and different life history traits may explain this result. According to Winemiller (1989), species of the genus Cichla exhibit equilibrium strategy characteristics (i.e., comparatively large oocytes, brood protection, small clutches, and acyclic spawning), whereas $P$. squamosissimus exhibits the similar season strategy (i.e., large clutches and small investment per offspring) as well as multiple spawning episodes throughout the year, with a reproductive peak in the rainy season. Thus, even affected by a high mortality during its first life stages, these characteristics may have been fundamental to a quick and successful colonization and expansion of $P$. squamosissimus in the reservoir. Although $C$. monoculus has a high survival rate during the juvenile phase, its large investment in reproduction may result in slower colonization of the environment. Furthermore, interactions with other species, physico-chemical characteristics of the environment, and the introduction date in the reservoir, may have also influenced the different abundances of the two species.

For C. monoculus, the maximum lengths recorded were similar to those found in studies of Cichla spp. in other Brazilian watersheds where they had been introduced (Câmara, Chellappa, \& Chellappa, 2002; Chellapa, Câmera, Chellappa, Beveridge, \& Huntinford, 2003; Gomiero \& Braga, 2003; Souza, Fragroso-Moura, Fenerich-Verani, Rocha, \& Verani, 2008) but smaller than those recorded in studies conducted in the watersheds where the species originated (Winemmiler, Taphorn, \& Barbarino-Duque, 1997; Japsen, Winemiller, Taphorn, \& Rodriguez-Olarte, 1999). For $P$. squamosissimus, the maximum lengths also were similar to those in reservoirs where the species had been introduced (Vidotto-Magnoni \& Carvalho, 2009) and smaller than those in the native environment (Camargo \& Junior, 
2007). It is important to emphasize that the length distribution of introduced species vary according to time they were introduced, the characteristics of the ecosystem, and the interactions with local fish species (Gomiero \& Braga, 2003).

In the length-weight relationship, the coefficient $b$ is considered to be a measure of relative growth and a reflection of recent food conditions, and its value can oscillate from 2.5 to 3.5 (Froese, 2006). The $b$ values for $P$. squamosissimus and C. monoculus were within the range of oscillation and similar to those estimated in other works (Winemmiler et al., 1997; Japsen et al., 1999; Gomiero \& Braga, 2003; Souza et al., 2008; Vidotto-Magnoni \& Carvalho, 2009), but in our study the two species demonstrated a positive allometric growth pattern. A study of Cichla ocellaris in places where it was recently introduced showed that the growth rate, and consequently the coefficient of relative growth $(b)$ of the lengthweight relationship, was generally high; the reason for this is that soon after introduction, the absence of predators and the large prey supply allow growth to increase at first, after which the relationship tends to decline due to predation and competition (Zaret, 1980). This may explain the positive allometric growth observed in our study, considering that the Santa Cruz Reservoir is new and that $P$. squamosissimus and C. monoculus were introduced soon after its installation.

The sex ratio of most fish species in the wild tends to be $1: 1$, but deviations can occur and seasonal variations are common (Helfman, Collette, Facey, \& Bowen, 2007). The sex ratio may be influenced by several factors, including mortality rate, longevity and growth rate, and reproductive behaviour, and these in turn lead to differences in the catch rate (Novaes \& Carvalho, 2011). For C. monoculus, a possible explanation for the observed difference in the sex ratio may be parental care; during the reproductive period, males exhibit aggressive territorial defence and protection of their offspring from any kind from invaders while females guard the eggs and larvae, leave males more vulnerable to capture (Japsen, Winemiller, \& Taphorn, 1997; Gomiero, Villares Jr., $\&$ Naous, 2009). Plagioscion squamosissimus does not practice parental care, so factors such as mortality rate and growth rate differentials between the sexes may have caused the observed difference in the sex ratio.

The size at first maturity for $P$. squamosissimus and C. monoculus in the Santa Cruz Reservoir was smaller than the estimates reported by other authors for the same species or for other species of these genera. The differences in size at first maturation can be attributed to several factors, such as species differences, methods of determining the size at first maturation, or adaptation to the environment (Helfman et al., 2007). Most previous works, Carnelós and Benedito-Cecilio (2002), Chellappa et al. (2003) and Gomiero and Braga (2004), used the method described by Vazzoler (1996), where the fit is manual. Souza et al. (2008) considered the size at first maturation to be the shortest length at which individuals at the advanced maturation stage were found. However, the logistic regression method used in our study and by Rocha et al. (2006), Camargo and Júnior (2007), Santos, Gonzalez and Araújo (2001), and Barbosa, Rocha and Frédou (2012) is more robust and more suitable for this analysis (King, 2007), therefore, the estimates made using this method are more reliable. According with King (2007) other factors that may have caused the difference in size at first maturation include: (1) Food availability: In the Santa Cruz Reservoir P. squamosissimus and $C$. monoculus had an abundance of food, as suggested the length-weight relationship with $a b$ value near 3 , so the fish could allocate enough energy to growth and early maturation; (2) Absence of predators: With less energy expended to avoid predators, more energy could be allocated to maturation; and (3) High and constant temperature throughout the year in the region: at high temperature, the growth rate is higher.

The statistical analyses of the GSI data and reproductive and non-reproductive individuals showed that $P$. squamosissimus reproduced 
throughout the year without the well-defined reproductive peak. Our results contrast with other studies in which these species exhibited greater reproductive intensity during the hottest and rainiest months of the year (Braga, 2001; Carnelós \& Benedito-Cecilio, 2002; Luiz, Velludo, Peret, Filho, \& Peret, 2011; Barbosa et al., 2012). For $C$. monoculus the statistical analysis showed that the species did not reproduce throughout the year, but showed a long reproductive period that was not markedly seasonal. Similar results for the species were found in other studies (Gomeira \& Braga, 2004; Chellappa et al., 2003; Muñoz, Damme, \& Duponchelle, 2006; Souza et al., 2008; Gomiero et al., 2009; Normando et al., 2009; Vieira, Salvador, Melo, Santos, \& Bazzoli, 2009).

Overall, the results suggest that the P. squamosissimus and C. monoculus populations are established in the Santa Cruz Reservoir, with individuals reproducing all season and growing satisfactorily. The decrease in the abundance of these species over the course of the study seems to be related to the trophic depression period of the ecosystem. Our results are also in agreement with other studies of introduced species that established successfully in many reservoirs in Brazil (Santos, Rocha, \& Frédou, 2010; Chellappa et al., 2003; Santos, Silva, \& Viana, 2003; Novaes et al., 2004; Bennemann, Carpa, Galvez, \& Shibatta, 2006; Gomes, Dias, \& Branco, 2008; Stefani \& Rocha, 2009) and other countries (Japsen et al., 1997; Muñoz et al., 2006). Introduced species are extremely difficult to eradicate (Britton \& Orsi, 2012), but a proposal to manage and control them is necessary to minimize their potentially harmful effects on the local aquatic community. We suggest that managers encourage artisanal fisheries and sport fishing to target these species in the reservoir and that any norm of protection for these species should be drawn.

\section{RESUMEN}

Estructura poblacional y período reproductivo de dos especies introducidas de peces en una represa de una región semiárida brasileña.
Las especies de peces amazónicos Plagioscion squamosissimus (Sciaenidae) y Cichla monoculus (Cichlidae), se han introducido ampliamente en diferentes embalses en Brasil, y han causado muchos impactos negativos sobre la fauna de peces locales. El objetivo de este estudio fue evaluar la estructura poblacional (abundancia, estructura de tallas, relación talla-peso, proporción de sexos, y talla de primera madurez) y el período reproductivo de estas dos especies en la represa Santa Cruz, (construida en el 2002), situada en la región semiárida de Brasil. Las muestras se recogieron trimestralmente en ocho sitios de febrero 2010 a noviembre 2013 mediante redes de pesca (12 a $70 \mathrm{~mm}$ ). Los ejemplares capturados se contaron y se analizaron los siguientes datos biométricos y biológicos: longitud estándar, peso total, y datos reproductivos, tales como: sexo, peso y estado de madurez gonadal. Capturamos un total de 1071 ejemplares de $P$. squamosissimus y 156 de C. monoculus. Ambas especies mostraron mayor abundancia en el 2010, $0.004306 \mathrm{~m}^{2} \mathrm{x}$ h y $0.00022 \mathrm{~m}^{2} \mathrm{x}$ h, respectivamente, pero este parámetro disminuyó de 2010 a 2013. La longitud estándar osciló entre 6.4 y $46.2 \mathrm{~cm}$ para $P$. squamosissimus y 7.0 y 38.7 $\mathrm{cm}$ para $C$. monoculus. Las relaciones tallapeso fueron descritas por las siguientes ecuaciones: $\log 10 \mathrm{Wt}=-1.8349+3.0899 \log 10 \mathrm{Lp} \mathrm{y}$ $\mathrm{R} 2=0.9795$ para $P$. squamosissimus y $\log 10 \mathrm{Wt}$ $=-1.7944+3.0885 \log 10 \mathrm{Lp} \mathrm{y} \mathrm{Wt}=0.0160$ y $\mathrm{R} 2=0.9929$ para $C$. monoculus; ambas especies mostraron un crecimiento alométrico positivo. La proporción de sexos para ambas especies difirió de 1:1, con un predominio de hembras en $P$. squamosissimus y machos en C. monoculus. El LP50 se estimó en $15.90 \mathrm{~cm}$ para $P$. squamosissimus y $15.65 \mathrm{~cm}$ para $C$. monoculus, los datos de reproducción indicaron que ambas especies se reproducen durante todo el año. Llegamos a la conclusión de que aunque la población de ambas especies redujo su abundancia durante el período de estudio, $P$. squamosissimus y $C$. monoculus están establecidas y estructuradas en la represa Santa Cruz con individuos creciendo satisfactoriamente y reproduciéndose en todas las estaciones, sin 
un pico reproductivo bien definido. Sugerimos que los administradores permitan que la pesca artesanal y / o deportivas de estas especies.

\section{ACKNOWLEDGMENTS}

We thank the entire team of the Laboratory for Fish Ecology and Artisanal Fisheries; and the financial support agencies, the Conselho Nacional de Desenvolvimento Científico e Tecnológico (CNPQ), Fundação de Apoio a Pesquisa do Estado do Rio Grande do Norte (FAPERN) and the Instituto Nacional do Semiárido (INSA), agreements $\mathrm{N}^{\mathrm{o}} 68.0025 / 2005 / 7$

- CNPq/FAPERN and $\mathrm{N}^{\mathrm{o}} 562525 / 2010-6$ - CNPq/INSA.

\section{REFERENCES}

Ab'Sáber, A. N. (1995). The caatinga domain. In S. Monteiro \& L. Kaz (Eds.), Caatinga-sertão, sertanejos (pp. 47-55). Rio de Janeiro: Editora Livroarte.

Agostinho, A. A., Gomes, L. C., Verissímo, S., \& Okada, E. K. (2004). Flood regime, dam regulation and fish in the upper Parana River: effects on assemblage attributes, reproduction and recruitment. Reviews in Fish Biology and Fisheries, 14(1), 11-19.

Agostinho, A. A., Gomes, L. C., \& Pelicice, F .M. (2007). Ecologia e manejo de rescursos pesqueiros em reservatórios do Brasil. Maringá, Brazil: EDUEM.

Almeida, S. A. S., Cullar, M. Z., Costa, A. M. B., \& Amorim, R. F. (2006). Caracterização das bacias hidrográficas do rio Apodi/Mossoró e Piranhas/Assú (RN): Mapeamento do uso do solo através das imagens do satellite CBERS 2 e análise socioeconômico. Revista FAPERN, 4(1), 5-9.

Barbosa, N. D., Rocha, R. M., \& Frédou, L. (2012). The reproductive biology of Plagioscion squamosissimus (Heckel, 1840) in the Pará River estuary (Amazon Estuary). Journal of Applied Ichthyology, 28, 800805. doi: 10.1111/j.1439-0426.2012.02040.x

Barros, L. C., Santos, L., Zanncio, L., \& Dergam, J. A. (2012). Plagioscion squamosissimus (Sciaenidae) and Parachromis managuensis (Cichlidae): A threat to native fish on the Doce River im Minas Gerais, Brazil. PLOS ONE, 7(6). Retrieved from http://www.plosone. org/article/info\%3Adoi\%2F 10.1371\%2Fjournal. pone. 0039138

Bennemann, S. T., Carpa, L. G., Galves, W., \& Shibatta, O. A. (2006). Dinâmica trófica de Plagioscion squamosissimus (Perciformes, Sciaenidae) em trecho de influência da represa Capivara (rio Paranapanema e Tibagi). Iheringia Série Zoologia, 96(1), 115-119.

Bond, N. R., Lake, P. S., \& Arthington, A. H. (2008). The impacts of drought on freshwater ecosystems: an Australian perspective. Hydrobiologia, 600, 3-16. doi:10.1007/s10750-008-9326-Z

Braga, F. M. S. (2001). Reprodução de peixes (Osteichthyes) em afluentes do reservatório de Volta Grande, rio Grande, sudeste do Brasil. Ihringia Série Zoologia, 91(1), 67-74.

Britton, J. R. \& Orsi, M. L. (2012). Non-native fish in aquaculture and sport fishing in Brazil: economic benefits versus risks to fish diversity in the upper River Paraná basin. Reviews in Fish Biology and Fisheries, 22, 555-565. doi: 10.1007/s11160-012-9254-x

Brown-Peterson, N. J., Wyanski, D. M., Saborido-Rey, F., Macewicz, B. J., \& Lowerre-Barbieri, S. K. (2011). A standardized terminology for describing reproductive development in fishes. Marine and Costal Fisheries: Dynamic, Management and Ecosystem Science, 3, 52-70. doi: 10.1080/19425120.2011.555724

Camargo, M. \& Júnior, W. M. A. L. (2007). Aspectos da biologia reprodutiva de seis espécies de peixes de importância commercial do médio rio Xingu - bases para manejo. UAKARI, 3(1), 64-77.

Câmara, M. R., Chellappa, N. T., \& Chellappa, S. (2002). Ecologia reprodutiva do Cichla monoculus, um ciclídeo amazônico no semi-árido do Rio Grande do Norte. Acta Limnologica Brasiliensia, 14(2), 9-16.

Carnelós, R. C., \& Benedito-Cecilio, E. (2002). Reproductive strategies of Plagioscion squamosissimus Heckel, 1840 (Osteichthyes Sciaenidae) in the Itaipu, Brazil. Brazilian Archives of Biology and Technology, 45(3), 317-324.

Castro, A. C. L. (1999). Tamanho e idade de primeira maturação da corvina, Plagioscion squamisissimus (Heckel, 1940), (Teleostei, Sciaenidae), do Reservatório de Barra Bonita-SP. Boletim do Museu Paraense de Zoologia Emílio Goeldi, 15(2), 119-132.

Casatti, L. (2003). Sciaenidae (Drums or croakers). In R. E. Reis, \& C. J. Ferraris (Eds.), Checklist of the freshwater fish of South and Central America (pp. 509-602). Porto Alegre, Brazil: EDIPUCRS.

Chellappa, S., Câmara, M. R., Chellappa, N. T., Beveridge, M. C. M., \& Huntingford, F. A. (2003). Reproductive ecology of a Neotropical cichlid fish, Cichla monoculus (Osteichthyes: Cichlidae). Brazilian Journal of Biology, 63(1), 17-26.

Chellapa, S., Bueno, R. M. X., Chellappa, T., Chellappa, N., \& Val, V. M. F. A. (2009). Reproductive seadonality of fish fauna and linmocology of semiarid Brazilian reservoirs. Limnologica, 39, 325-329. doi:10.1016/j.limno.2009.06.003 
Froese, R. (2006). Cube law, condition factor and weightlength relationships: history, meta-analysis and recommendations. Journal of Applied Ichthyology, 22, 241-253. doi:10.1111/j.1439-0426.2006.00805.x

Froese, R., \& Pauly, D. (2014) FishBase. Retrieved from www.fishbase.org

Godinho, A. L., Lamas, I. R., \& Godinho, H. P. (2010). Reproductive ecology of Brazilian freshwater fishes. Environmental Biology of Fishes, 87, 143-162. doi: 10.1007/s10641-009-9574-4

Gomes, J. H. C., Dias, A. C. I. M., \& Branco, C. C. (2008). Fish assemblage composition in three reservoirs in the State of Rio de Janeiro. Acta Limnologica Brasiliensia, 20(4), 373-380.

Gomiero, L. M., \& Braga, F. M. S. (2003). Relação pesocomprimento e fator de condição para Cichla ocellaris e Cichla monoculus (Perciformes, Cichlidae) no reservatório de Volta Grande, rio Grande - MG/SP. Acta Scientiarum. Biological Sciences, 25(79), 79-86.

Gomieiro, L. M., \& Braga, F. M. S. (2004). Reproduction of species of the genus Cichla in a reservoir in southeaster Brazil. Brazilian Journal of Biology, 63(4), 613-624.

Gomiero, L. M., Villares Jr., G. A., \& Naous, F. (2009). Reproduction of Cichla kelberi Kullander \& Ferreira, 2006 introduced into an artificial lake in southeastern Brazil. Brazil. Brazilian Journal of Biology, 69(1), 175-183.

Gozlan, R. E., Britton, J. R., Cowx, I., \& Copp, G. H. (2010). Current knowledge on non-native freshwater fish introductions. Journal of Fish Biology, 76, 751786. doi:10.1111/j.1095-8649.2010.02566.x

Helfman, G. S., Collette, B. B., Facey, D. E., \& Bowen, B. W. (2007). The diversity of fish: Biology, Evolution and Ecology. Oxford, England: Wiley-Blackwell.

Japsen, D. B., Winemiller, K. O., \& Taphorn, D. C. (1997). Temporal patterns of resource partitioning among Cichla species in a Venezuela blackwater river. Journal of Fish Biology, 51(6), 1085-1108.

Japsen, D. B., Winemiller, K. O., Taphorn, D. C., \& Rodriguez-Olarte, D. (1999). Age structure and growth of peacock cichlid of rivers and reservoirs of Venezuela. Journal of Fish Biology, 55(2), 433-450.

King, M. (2007). Fisheries biology, assessment and management. Oxford, England: Blackwell Publishing

Kullander, S. O., \& Ferreira, E. J. G. (2006). A review of the South American cichlid genus Cichla, with descriptions of nine new species (Teleostei: Cichlidae). Ichthyological Exploration of Freshwaters, 17(4), 289-398.

Lowe-McConnell, R. H. (1987). Ecological studies in tropical fish communities. Cambridge, England: Cambridge.
Luiz, T. F., Velludo, M. R., Peret, A. C., Filho, J. L. R., \& Peret. A. M. (2011). Diet, reproduction and population structure of the introduced Amazonian fish Cichla piquiti (Perciformes: Cichlidae) in the Cachoeira Dourada reservoir (Paranaíba River, central Brazil). Revista de Biología Tropical, 59(2), 727-741.

Muñoz, H., Damme, P. A., \& Duponchelle, F. (2006). Breeding behaviour and distribuition of the tucunaré Cichla aff. monoculus in a clear water river of the Bolivian Amazon. Journal of Fish Biology, 69, 10181030. doi:10.1111/j.1095-8649.2006.01177.x

Normando, F. T., Arantes, F. P., Luz, R. K., Thomé, R. G., Rizzo, E., Sato, Y., \& Bazzoli, N. (2009). Reproduction and fecundity of tucunaré, Cichla kelberi (Perciformes: Cichlidae), an exotic species in Três Marias Reservoirs, Southeastern, Brazil. Journal of Applied Icththyology, 25, 299-305. doi: 10.1111/j.1439-0426.2008.01174.x

Novaes, J. L. C., \& Carvalho, E. D. (2011). Population structure and stock assessment of Hoplias maculatus (Characiformes: Erythrinidae) caught by artisanal fishermen in river-reservoir transition area in Brazil. Revista de Biología Tropical, 59(1), 71-83.

Novaes, J. L. C., Caramaschi, E. P., \& Winemiller, K. O. (2004). Feeding of Cichla monoculus Spix, 1829 (Teleostei: Cichlidae) during and after reservoir formation in the Tocantins River, Central Brazil. Acta Limnologica Brasiliensia, 16(1), 41-49.

Paiva, M. P., Petrere Jr., M., Petenate, A. J., Nepomuceno, F. H., \& Vasconcelos, E. A. (1994). Relationship between the number of predatory species and fish yield in large northeastern Brazilian reservoirs. In I. G., Cowx (Ed.), Rehabilitation of freshwater fisheries (pp.120-129). London: Fishing News Books.

Petrere Jr., M. (1996). Fisheries in large tropical reservoirs in South America. Lakes and Reservoirs: Research and Management, 2(1-2), 111-133.

Petry, A. C., Agostinho, A. A., \& Gomes, L. C. (2003). Fish assemblage of tropical floodplain lagoons: exploring the role of connectivity in a dry year. Neotropical Ichthyology, 1(2), 111-119.

R Development Core Team. 2013. R: A language and environment for statistical computing. R Foundation for statistical computing, Vienna, Austria. Retrieved from http://www.R-project.org.

Rocha, J. C., Juras, A. A., Cintra, I. H. A., \& Souza, R. F. C. (2006). A reprodução da pesca-branca Plagioscion squamosissimus (Heckel, 1840) (Perciformes: Sciaenidae) no reservatório da usina hidroéelétrica de Tucuruí (Pará-Brasil). Boletim Técnico-Científico do Cepnor, 6(1), 49-60.

Rosa, R., Menezes, N. A., Britski, H., Costa, W. J. E. M., \& Groth, F. (2003). Diversidade, padrões de distribuição e conservação dos peixes da caatinga. In I. R. Leal, M. Tabarelli, \& J. C. S. Silva (Eds.), Ecologia 
e conservação da caatinga (pp. 135-181). Recife: Editora Universitária.

Santos, L. N., Gonzalez, A. F., \& Araújo, F. G. (2001). Dieta do tucunaré-amarelo Cichla monoculus (Bloch \& Schneider) (Osteichthyes, Cichlidae), no reservatório de Lajes, Rio de Janeiro, Brasil. Zoologia, 18(1), 191-204.

Santos, S. B. A. F., Silva, A. C., \& Viana, M. S. R. (2003). Aspectos reprodutivos da pesca-do-piauí, Plagioscion squamosissimus (Heckle, 1840), capturada no açude Pereira de Miranda (Pentecoste - Ceará). Revista de Ciências Agronômicas, 34(1), 5-10.

Santos, N. B., Rocha, R. M., \& Fredóu, F. L. (2010). Reproductive biology of Plagioscion magdalenae (Teleostei: Sciaenidae) (Steindacnher, 1878) in the bay of Marajo, Amazon Estuary, Brazil. Neotropical Ichthyology, 8(2), 333-340.

Souza, J. E., Fragoso-Moura, E. N., Fenerich-Verani, N., Rocha, O., \& Verani, J. R. (2008). Population structure and reproductive biology of Cichla kelberi (Perciformes, Cichlidae) in Lobo Reservoir, Brazil. Neotropical Ichthyology, 6(2), 201-201.

Stefani, P. M., \& Rocha, O. (2009). Diet composition of Plagioscion squamosissimus (Heckel, 1840), a fish introduced into the Tietê River system. Brazilian Journal of Biology, 69(3), 805-812.
Vazzoler, A. E. A. M. 1996. Biologia da reprodução de peixes teleósteos: teoria e prática. Maringá, Brazil: Eduem.

Vidotto-Magnoni, A. P., \& Carvalho, E. D. (2009). Population biology of dominant fish species of Santa Bárbara river, a tributary of the Nova Avanhandava reservoir (low Tietê River, São Paulo State, Brazil). Acta Scientiarum. Biological Sciences, 31(1), 55-63.

Vieira, A. B. C., Salvador Jr., L. F., Melo, R. M. C., Santos, G. B., \& Bazzoli, N. (2009). Reproductive biology of the peacock bass Cichla piquiti (Perciformes: Cichlidae), an exotic species in a Neotropical reservoir. Neotropical Ichthyology, 7(4), 745-750.

Winemiller, K. O. (1989). Patterns of variation in the life history among South American fishes in seasonal environments. Oecologia, 81(2), 225-241.

Winemiller, K. O., Taphorn, D. C., \& Barbarino-Duque, A. (1997). Ecology of Cichla (Cichlidae) in two blackwater rivers of Southern Venezuela. Copeia, 1997(4), 690-696.

Wootton, R. J. (1995). Ecology of teleost fishes. London, England: Chapman \& Hall.

Zar, J. H. (1996). Biostatistical analysis. New Jersey, USA: Prentice-Hall.

Zaret, T. M. 1980. Life history and growth relationship of Cichla ocellaris, a predatory South American cichlid. Biotropica, 12(2), 144-157. 
